\title{
Analisis dan Perancangan Aplikasi Berbasis Web untuk Pengajuan Topik Tugas Akhir
}

\author{
http://dx.doi.org/10.28932/jutisi.v7i2.3704 \\ Riwayat Artikel \\ Received: 18 Juni 2021 | Final Revision: 13 Juli 2021 | Accepted: 16 Juli 2021
}

\author{
Meliana Christianti Johan ${ }^{\bowtie \# 1}$, Erico Darmawan Handoyo ${ }^{* 2}$, Sulaeman Santoso $^{\# 3}$, Christian Chastro ${ }^{* 4}$ \\ \# Program studi S1 Teknik Informatika, Universitas Kristen Maranatha \\ Jl. Surya Sumantri No. 65 Bandung 40164 \\ ${ }^{1}$ meliana.christianti@it.maranatha.edu \\ ${ }^{3}$ sulaeman. santosodit.maranatha.edu \\ *Program studi S1 Teknik Informatika, Universitas Kristen Maranatha \\ Jl. Surya Sumantri No. 65 Bandung 40164 \\ ${ }^{2}$ erico.dheit.maranatha.edu \\ ${ }^{4}$ it1672006estudent.it.maranatha.edu
}

\begin{abstract}
Maranatha Christian University Bandung is one of the universities in Indonesia that has a Faculty of Information Technology. In the Faculty of Information Technology there is an Informatics Engineering Study Program. The thing that underlies this research is that there is currently no integration between the Practical Work courses and the Final Project courses. For this reason, this research will try to analyze and design one application that will be carried out. The hope of this research is to help the process of submitting practical work topics and students' final assignments so that data is integrated and the recording process is better because it uses a web-based application. This application is a web-based application so it can be used anytime and anywhere.
\end{abstract}

Keywords- Application; Final Project Courses; Practical Work Courses; Web-Based.

\section{PEndahuluan}

Universitas Kristen Maranatha Bandung adalah salah satu perguruan tinggi di Indonesia yang memiliki Fakultas Teknologi Informasi. Di Fakultas Teknologi Informasi ada Program Studi yaitu Teknik Informatika. Pada program studi tersebut terdapat mata kuliah wajib yang harus diselesaikan oleh mahasiswa yaitu mata kuliah Seminar Tugas Akhir dan Tugas Akhir. Mata kuliah tersebut mempunyai proses yang berbeda dengan mata kuliah lainnya. Analisis dan perancangan sistem yang dilakukan dalam penelitian ini bertujuan untuk menghasilkan aplikasi yang dapat digunakan untuk mengelola proses pengajuan topik tugas akhir dari mahasiswa sehingga proses pengajuan topik dapat tercatat dengan lebih baik. Aplikasi yang dibuat dalam penelitian ini adalah aplikasi berbasis web yang dibuat menggunakan bahasa pemrograman PHP dan basis data menggunakan MySQL.

Berdasarkan latar belakang permasalahan yang dihadapi maka pembuatan aplikasi dalam penelitian ini akan berfokus pada pembuatan aplikasi yang dapat digunakan untuk mengelola proses pengajuan topik Seminar Tugas Akhir dari mahasiswa yang menjadi peserta di mata kuliah Seminar Tugas Akhir (STA) dan nantinya akan dilanjutkan menjadi topik Tugas Akhir (TA) di Program Studi S1 Teknik Informatika Universitas Kristen Maranatha.

\section{Metode Penelitian}

Usaha untuk mengembangkan sistem administrasi untuk tugas akhir telah banyak dilakukan namun dengan spesifikasi dan keperluan yang berbeda beda. Sebagai contoh Mohammad Arief menyatukan sistem kerja praktek dan tugas akhir [1] namun sistem ini hanya mencakup aspek bimbingan dari tugas akhir maupun kerja praktek. Beberapa pendekatan sudah mencakup aspek sidang dan penilaian namun umumnya bersifat statis seperti pendekatan yang dilakukan oleh Arifin Mohammad [2], Septya [3], dan Insan [4].

Sistem administrasi tugas akhir yang hendak dikembangkan memiliki kaitan yang erat dengan beberapa sistem yang sudah terlebih dahulu dikembangkan, salah satu sistem pernah dibuat pada tahun 2019. Namun sistem tersebut dirasakan 
masih memiliki kekurangan, dimana proses yang dibuat dalam sistem tersebut tidak mengambil proses dari awal pengajuan Topik Seminar Tugas Akhir tapi hanya mengambil bagian penilaian saja. Sistem Administrasi Tugas Akhir yang sudah pernah dibuat adalah aplikasi yang dikembangkan untuk digunakan oleh koordinator dan dosen yang terlibat dalam sidang mahasiswa saja. Sehingga, pengembangan sistem administrasi tugas akhir ini akan dikembangkan dengan mempertimbangkan pengembangan sistem kerja praktek yang telah berjalan di Program Studi S1 Teknik Informatika.

Sistem kerja praktek yang telah dikembangkan memiliki proses yang hampir serupa dengan tugas akhir sehingga hal tersebut dapat menjadi acuan untuk pengembangan sistem tugas akhir lebih lanjut. Sistem kerja praktek di Program Studi S1 Teknik Informatika pertama kali dibuat oleh Radiant Victor Imbar dan Adelia et al [1]. Sistem tersebut telah mengalami dua kali peremajaan yaitu oleh Bertha Alan et al (2018) [6] lalu oleh Christian Chastro et al (2020) [7]. Hal tersebut terjadi karena adanya perubahan proses dan keperluan untuk digitalisasi proses dan untuk mengurangi pemakaian bahan fisik [5].

Penelitian ini akan memperbaharui sistem administrasi tugas akhir dan menjadi modul awal dari modul selanjutnya yang akan dikembangkan. Gambar 1 menunjukkan rancangan pengembangan sistem yang diharapkan dapat diselesaikan mulai dari penelitian ini dan penelitian selanjutnya. Dalam penelitian ini, fokus fitur utama yang dikerjakan ada pada proses pertama dan kedua yaitu proses pengajuan topik dan penerimaan topik berdasarkan rapat Fakultas. Berdasarkan alur penelitian yang telah dijelaskan sebelumnya, maka dengan demikian, sistem yang dihasilkan dalam penelitian yang sedang dilaksanakan saat ini difokuskan pada pendaftaran topik, penentuan pembimbing maupun penguji, karena proses penentuan dosen ditentukan melalui rapat Fakultas. Setelah penelitian ini dilaksanakan, rencana selanjutnya adalah mengembangkan aplikasi untuk proses bimbingan, pengajuan sidang dan penilaian TA.

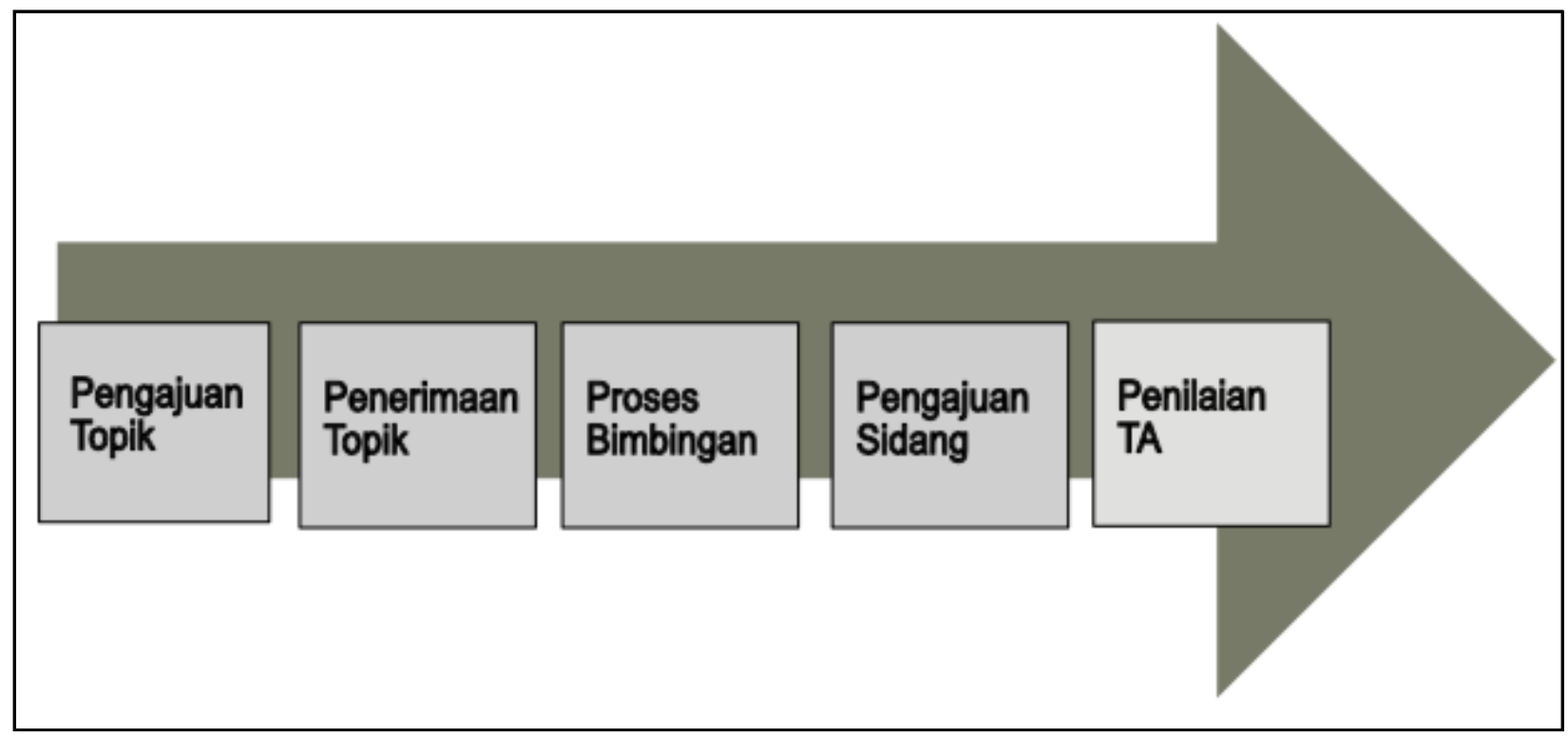

Gambar 1.Alur Penelitian Sistem Administrasi Tugas Akhir Secara Keseluruhan

Gambar 2 menunjukkan diagram use case [8] dari sistem yang secara menyeluruh ingin dihasilkan dari penelitian ini. Meskipun saat ini penelitian yang sudah berhasil diselesaikan berfokus pada proses pengajuan topik dari mahasiswa yang mengambil mata kuliah Seminar Tugas Akhir. Dalam use case diagram tersebut dapat dilihat bahwa koordinator dapat mengelola tahun ajaran, menentukan pembimbing dan penguji (data dimasukkan berdasarkan rapat fakultas), mengelola data nilai, mengelola data sidang, mengelola data topik, mengelola data topik, dan mengelola data dosen. Mahasiswa juga dapat mengakses aplikasi ini dimana mahasiswa dapat mengajukan topik dan melihat jadwal sidang. Secara keseluruhan sistem yang diharapkan tergambar dalam use case diagram tersebut. Namun untuk penelitian ini, fitur utama yang dihasilkan ada pada proses pengajuan topik dari mahasiswa dan proses pengelolaan data topik. 


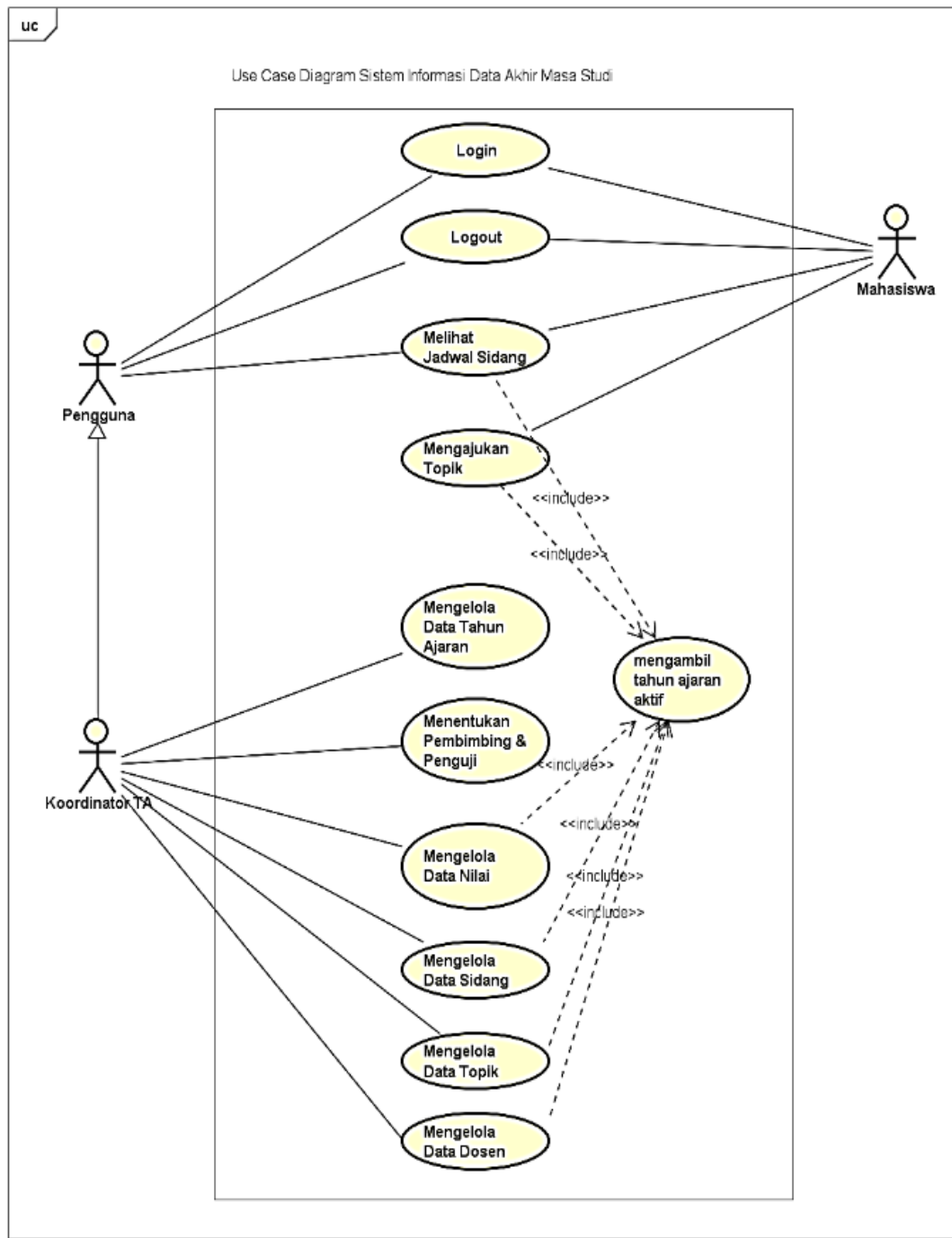

Gambar 2. Use Case Diagram Pengajuan Topik Mahasiswa

\section{HASIL DAN PEMBAHASAN}

Dalam penelitian ini, tahapan awal yang dilakukan mulai dari analisis hingga membuat rancangan aplikasi. Penelitian ini diharapkan dapat menghasilkan aplikasi berbasis web yang dapat diakses kapanpun dan dimanapun. Dalam penelitian ini metode yang dipilih menggunakan model prototipe. Langkah penelitiannya akan dimulai dengan tahap analisis, desain, pengembangan aplikasi dan pengujian sistem. Setelah menyelesaikan setiap tahapannya hasil penelitian ini dapat digunakan mulai Semester Ganjil 2021/2022. [9], [10], [11], [12].

\section{A. Hasil Penelitian}

Pada bagian ini, akan dibahas mengenai tampilan aplikasi yang telah berhasil dibuat. Dimana, tahapan pengajuan topik Tugas Akhir ditampilkan pada Tabel 1. Ketika mengakses aplikasi, mahasiswa diminta untuk melengkapi data diri lalu mengajukan topik. Mahasiswa diwajibkan untuk melengkapi data diri yang ada di menu profile. Jika data diri mahasiswa sudah lengkap barulah mahasiswa dapat mengajukan topik dan melengkapi dokumen yang diperlukan seperti DKBS dan Transkrip Nilai. Tahap selanjutnya mahasiswa perlu menunggu persetujuan dosen. Jika Sumber topik berasal dari dosen, maka mahasiswa perlu meminta konfirmasi dari dosen yang bersangkutan untuk bukti kepemilikan topik dari dosen. Pada tahap selanjutnya, koordinator TA akan memeriksa kelengkapan dokumen pengajuan topik. Apabila dokumen dinyatakan lengkap maka tahap berikutnya adalah Koordinator mengikuti rapat Fakultas bersama dengan koordinator Kelompok Bidang Keahlian (KBK) untuk menentukan dosen pembimbing untuk mahasiswa yang mengajukan topik. 
TABEL 1

Tahapan Pengajuan Topik Seminar Tugas AkhiR

\begin{tabular}{|c|c|}
\hline 1 & Melengkapi Data Diri dan Mengajukan Topik \\
\hline & $\begin{array}{l}\text { Sebelum mengajukan topik, mahasiswa diwajibkan untuk melengkapi } \\
\text { data diri yang ada di menu profile. Jika data diri mahasiswa sudah } \\
\text { lengkap barulah mahasiswa dapat mengajukan topik dan melengkapi } \\
\text { dokumen yang diperlukan seperti DKBS dan Transkrip Nilai. }\end{array}$ \\
\hline 2 & Menunggu Persetujuan Dosen \\
\hline & $\begin{array}{l}\text { Jika sumber topik berasal dari dosen, maka mahasiswa perlu meminta } \\
\text { konfirmasi dari dosen yang bersangkutan setelah mengajukan topik. }\end{array}$ \\
\hline 3 & Menunggu Persetujuan Koordinator TA \\
\hline & $\begin{array}{l}\text { Koordinator TA akan memeriksa kelengkapan dokumen pengajuan } \\
\text { topik sebelum tahap berikutnya. }\end{array}$ \\
\hline 4 & Menunggu Persetujuan Koordinator KBK \\
\hline & $\begin{array}{l}\text { Koordinator KBK akan melihat kelayakan dari topik yang diajukan } \\
\text { oleh mahasiswa. }\end{array}$ \\
\hline
\end{tabular}

\section{B. Pembahasan Prototype Aplikasi}

Pada bagian ini akan diperlihatkan tampilan aplikasi yang telah dihasilkan dari penelitian ini. Gambar 3 merupakan tampilan untuk koordinator Tugas Akhir. Menu yang pertama kali akses oleh koordinator adalah Menu Batch topik. Pada menu tersebut koordinator membuka batch pengajuan topik sehingga mahasiswa dapat mengajukan topik sesuai tanggal yang ditentukan oleh koordinator. Tampilan dari menu pengaturan batch pengajuan topik dapat dilihat pada Gambar 4 . Menu lainnya yang perlu diakses oleh koordinator setelah mahasiswa mengajukan topik adalah menu kelengkapan dokumen. Koordinator akan memeriksa berkas pengajuan topik Tugas Akhir dari mahasiswa dan memberikan keterangan lengkap / tidak lengkap pada aplikasi. Status tersebut dapat dilihat oleh mahasiswa.

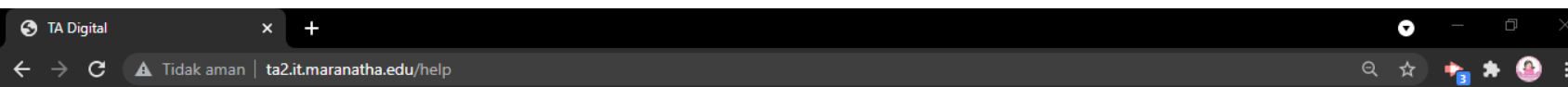

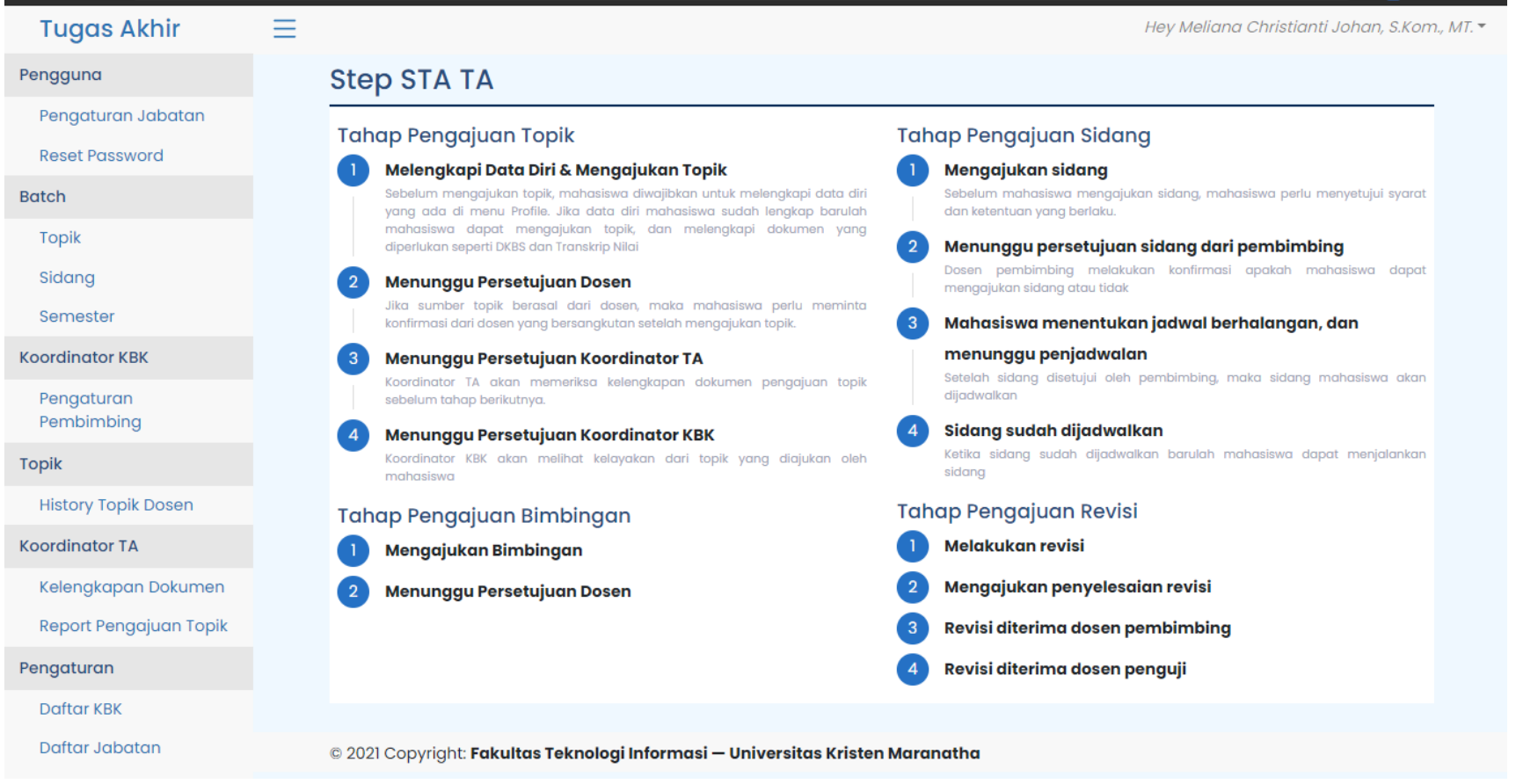

Gambar 3. Tampilan untuk Koordinator TA 


\section{(3) TA Digital $\quad x+\frac{0}{0} \times$ \\ $\leftarrow \rightarrow$ C A Tidak aman | ta2.itmaranatha.edu/batch/topik

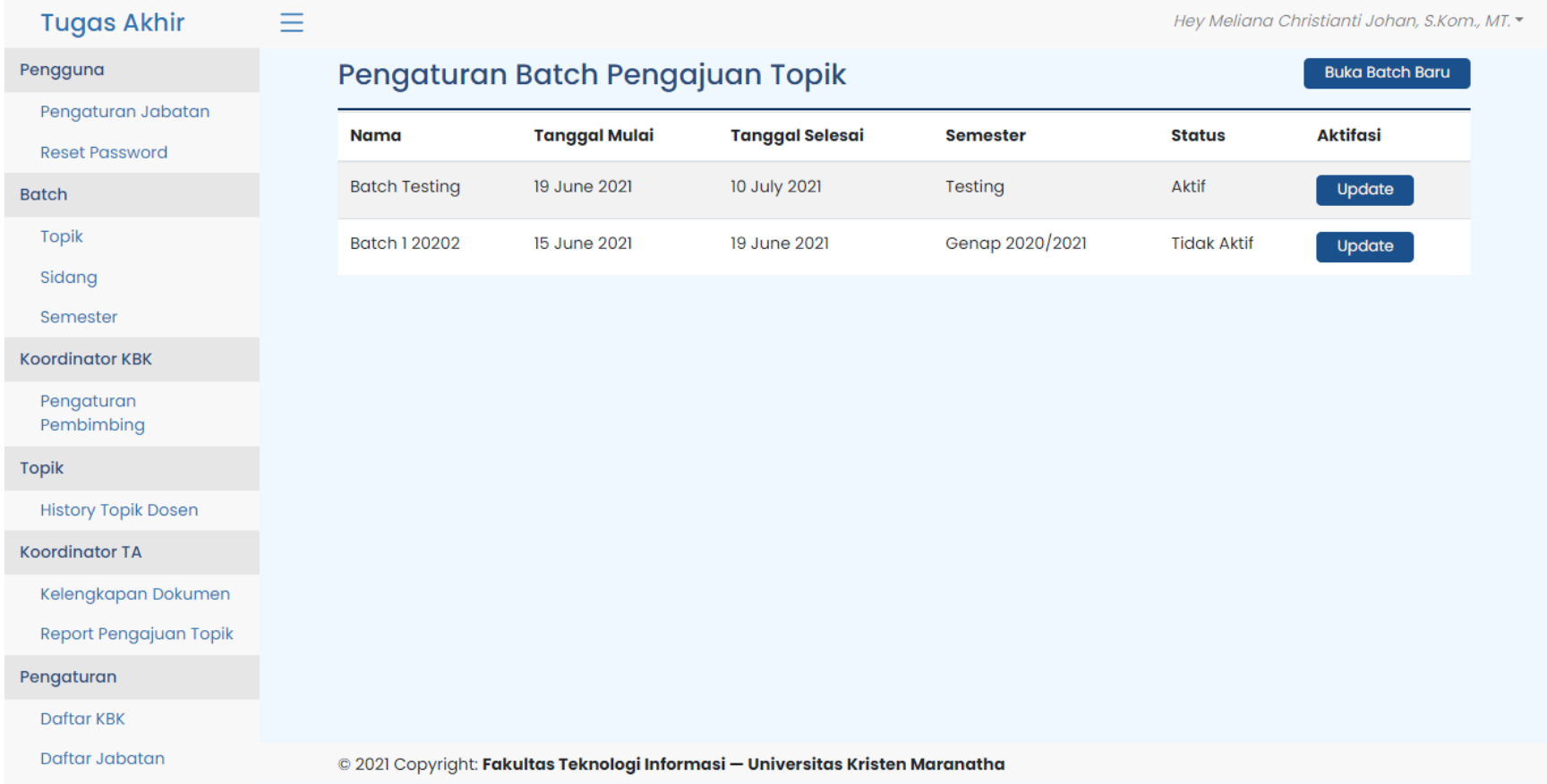

Gambar 4. Tampilan untuk Koordinator TA Mengatur Batch Pengajuan Topik

Pada Gambar 5 diperlihatkan tampilan untuk koordinator memeriksa kelengkapan dokumen pengajuan topik dari mahasiswa. Apabila ingin melihat detail status akhir kelengkapan koordinator dapat scroll halaman tersebut lalu melihat status akhir kelengkapan dokumen mahasiswa. Tampilan dapat dilihat pada Gambar 6 dan 7. Detail lainnya yang dapat dilihat adalah bagian komentar. Tampilan dapat dilihat pada Gambar 8. Setiap komentar dari koordinator dan user (Koordinator KBK / PJS yang terlibat dalam rapat penentuan kelayakan topik dan penentuan pembimbing) dapat dilihat secara jelas dan detail disertai dengan tombol yang berfungsi untuk memberikan keputusan untuk topik yang sudah diterima tidak bisa diubah lagi. Proses ini akan membantu memperjelas status / keputusan yang diberikan terhadap topik yang diajukan oleh mahasiswa untuk tugas akhirnya. 


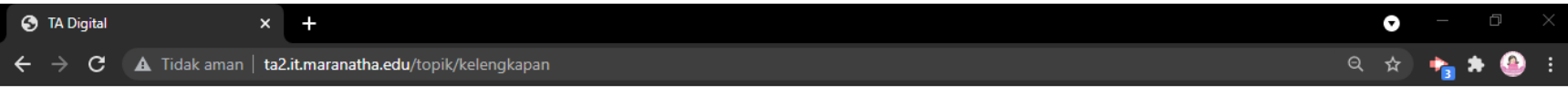

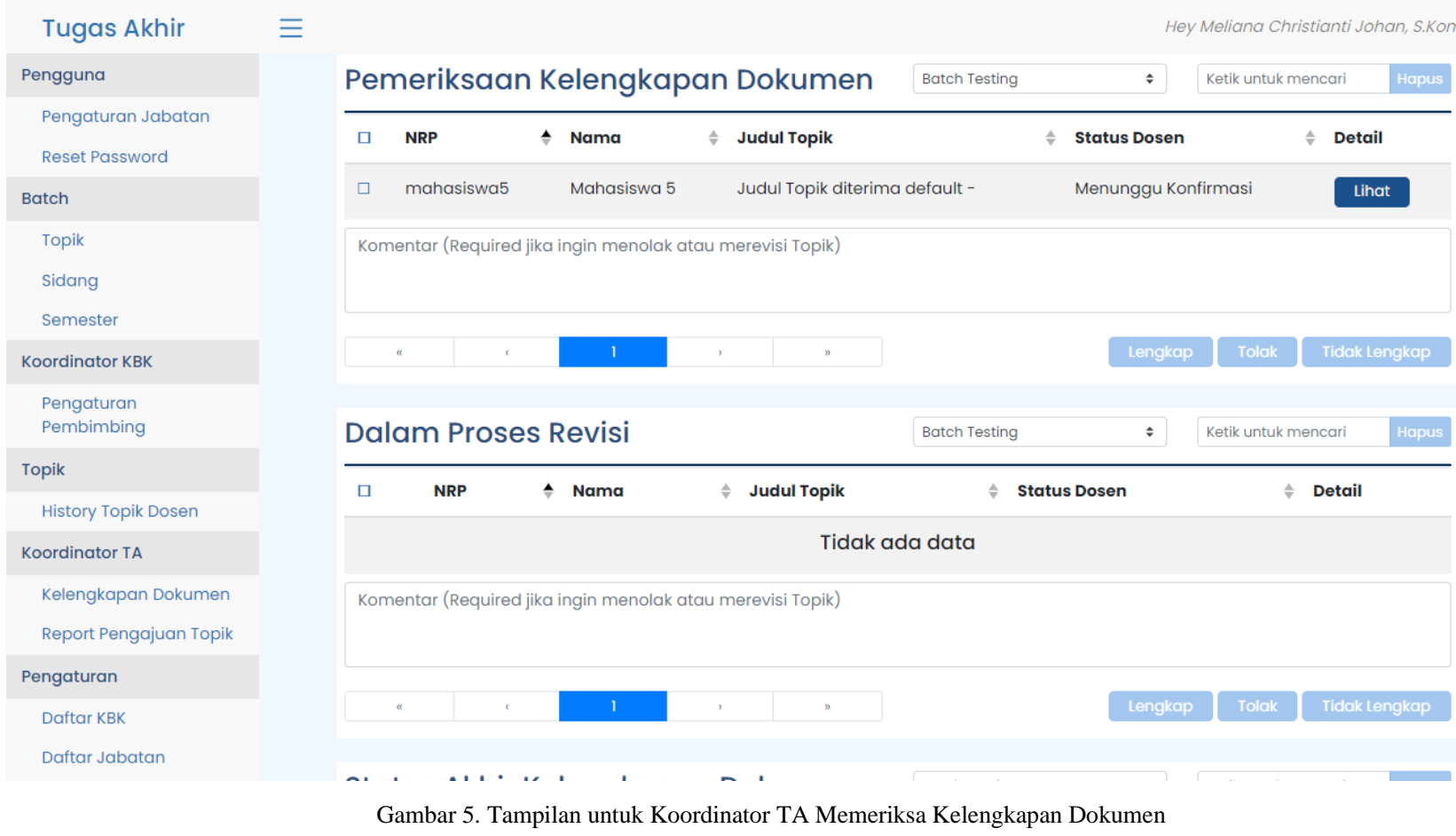

$\begin{array}{llll}\text { (5) TA Digital } & \times+ & - & 0 \\ \leftarrow \rightarrow C & \text { A Tidak aman } \mid \text { ta2.itmaranatha.edu/topik/kelengkapan } & \times\end{array}$

Daftar Jabatan

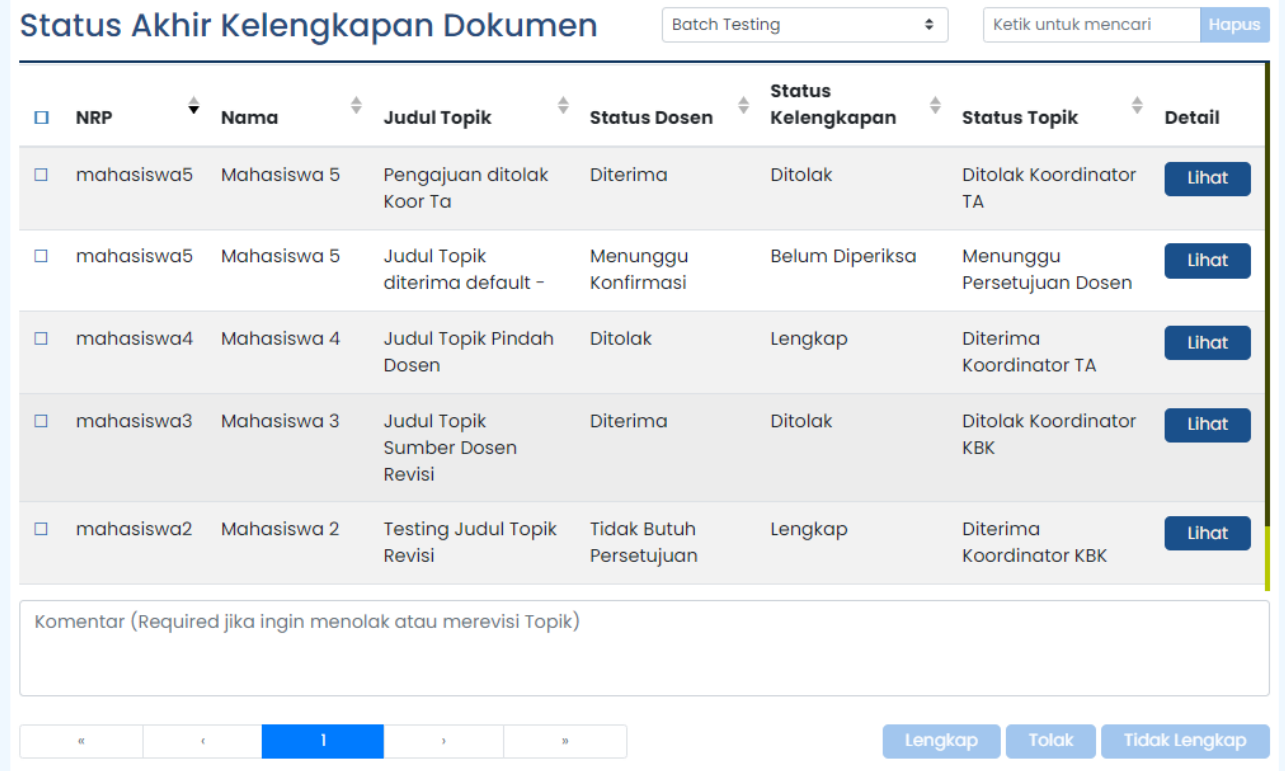

c) 2021 Copyright: Fakultas Teknologi Informasi - Universitas Kristen Maranatha

Gambar 6. Tampilan untuk Koordinator TA - Status Akhir Kelengkapan Dokumen 


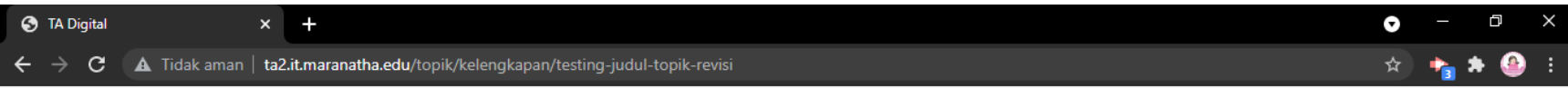

\begin{tabular}{|l|l|}
\hline Tugas Akhir \\
\hline Pengguna \\
\hline Pengaturan Jabatan \\
Reset Password \\
\hline Batch \\
\hline Topik \\
\hline Sidang \\
\hline Semester \\
\hline Koordinator KBK \\
\hline Pengaturan \\
\hline Pembimbing \\
\hline Topik \\
\hline History Topik Dosen \\
\hline Koordinator TA \\
\hline Kelengkapan Dokumen \\
\hline Report Pengajuan Topik \\
\hline Pengaturan \\
\hline
\end{tabular}

$\equiv$

Detail Topik STA

Mahasiswa 2 - mahasiswa2

\section{Deskripsi Topik}

Testing Deskripsi Topik Revisi

\section{Daftar Pustaka}

Testing Daftar Pustaka Topik

\section{KBK}

Multimedia dan Jaringan

Kelengkapan Topik
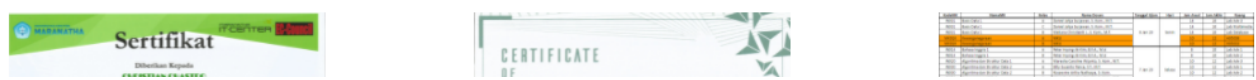

Gambar 7. Tampilan untuk Koordinator TA - Status Akhir Kelengkapan Dokumen (2)

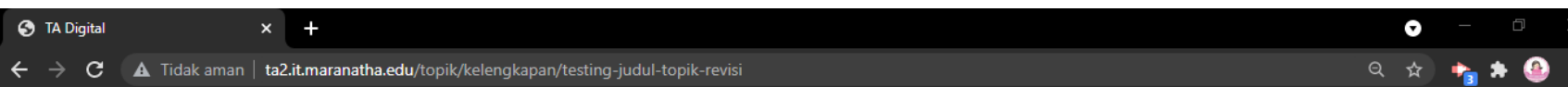

Komentar
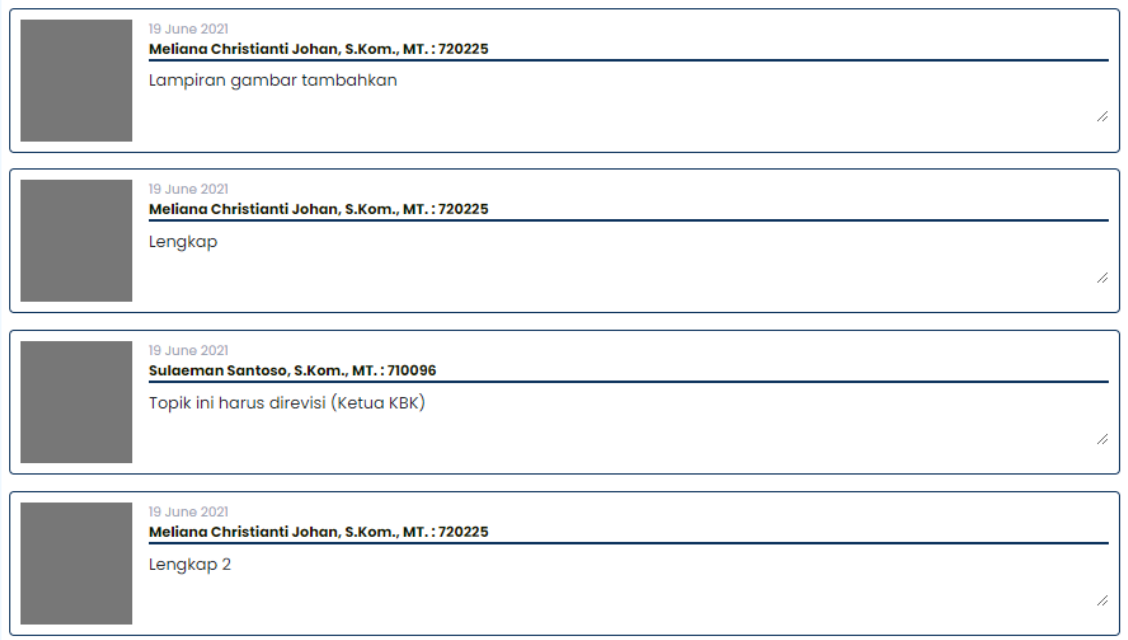

Komentar (Required jika ingin menolak atau merevisi Topik)

Topik yang sudah 'Diterima' tidak bisa di ubah lagi \begin{tabular}{llll}
\hline Lengkop Tolak Tidak Lengkap Migrasi KBK \\
\hline
\end{tabular}

C 2021 Copyright: Fakultas Teknologi Informasi - Universitas Kristen Maranatha

Gambar 8. Tampilan Komentar dari Menu Status Akhir Kelengkapan Dokumen 
Selanjutnya akan dibahas tampilan yang dilihat oleh akun mahasiswa. Pada Gambar 9 dan 10 diperlihatkan tampilan untuk mahasiswa dapat mengajukan topik tugas akhirnya. Mahasiswa diminta untuk menginputkan data judul topik, deskripsi topik, daftar pustaka, menentukan KBK, sumber topik, melampirkan beberapa dokumen yaitu DKBS, transkrip nilai terakhir, dan lampiran gambar lain (bila diperlukan).

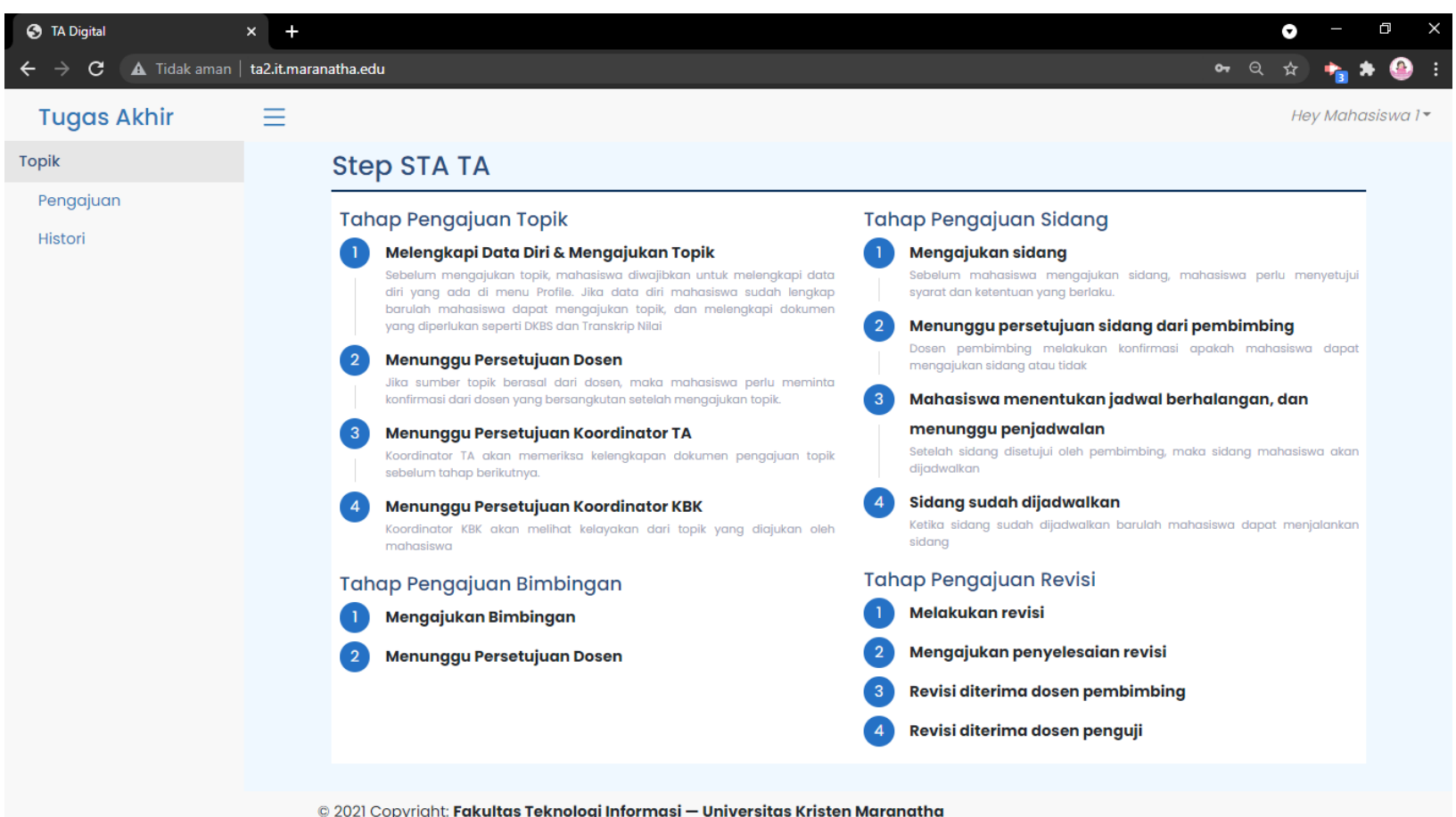

Gambar 9. Tampilan Pada Akun Mahasiswa

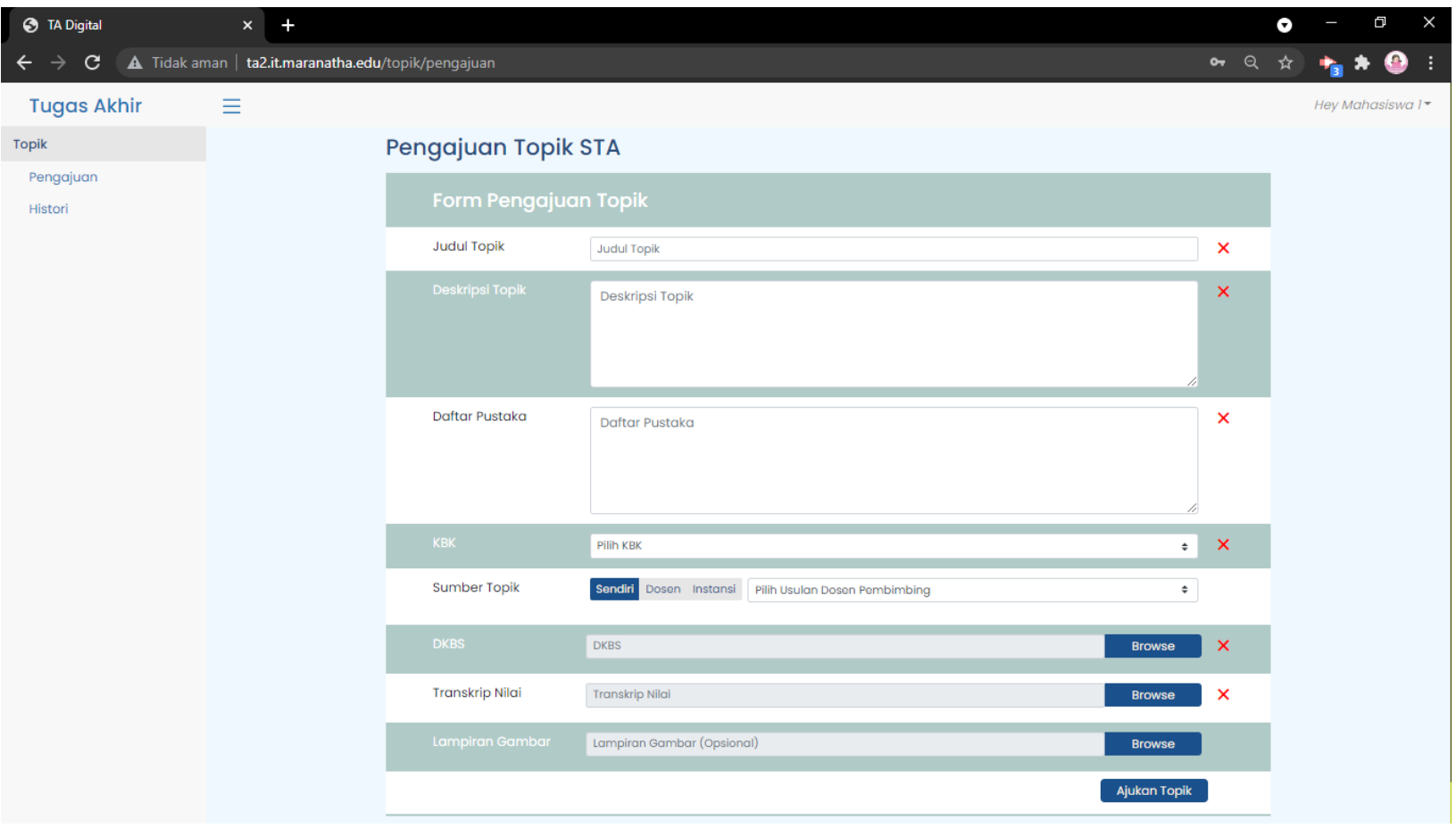

Gambar 9. Tampilan untuk Mahasiswa Mengajukan Topik 
Gambar 10 dan 11 merupakan tampilan detail topik yang diajukan mahasiswa dengan status pengajuan : Sedang diajukan. Mahasiswa mengikuti tahap pengajuan melalui aplikasi berbasis web. Mahasiswa dapat melihat detail topik pada menu histori sehingga mengetahui status pengajuannya.

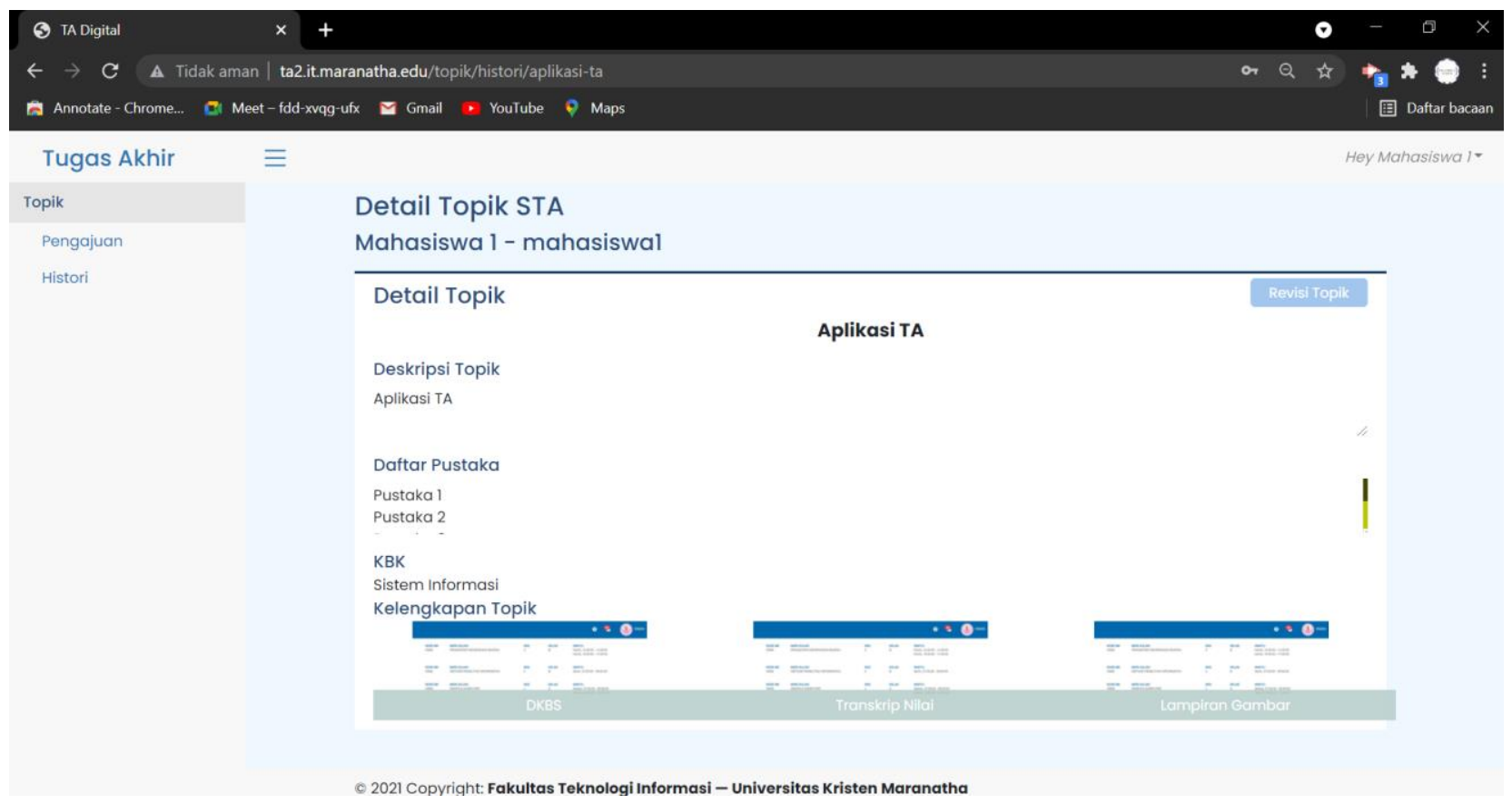

Gambar 10. Tampilan Pengajuan Topik dari Mahasiswa
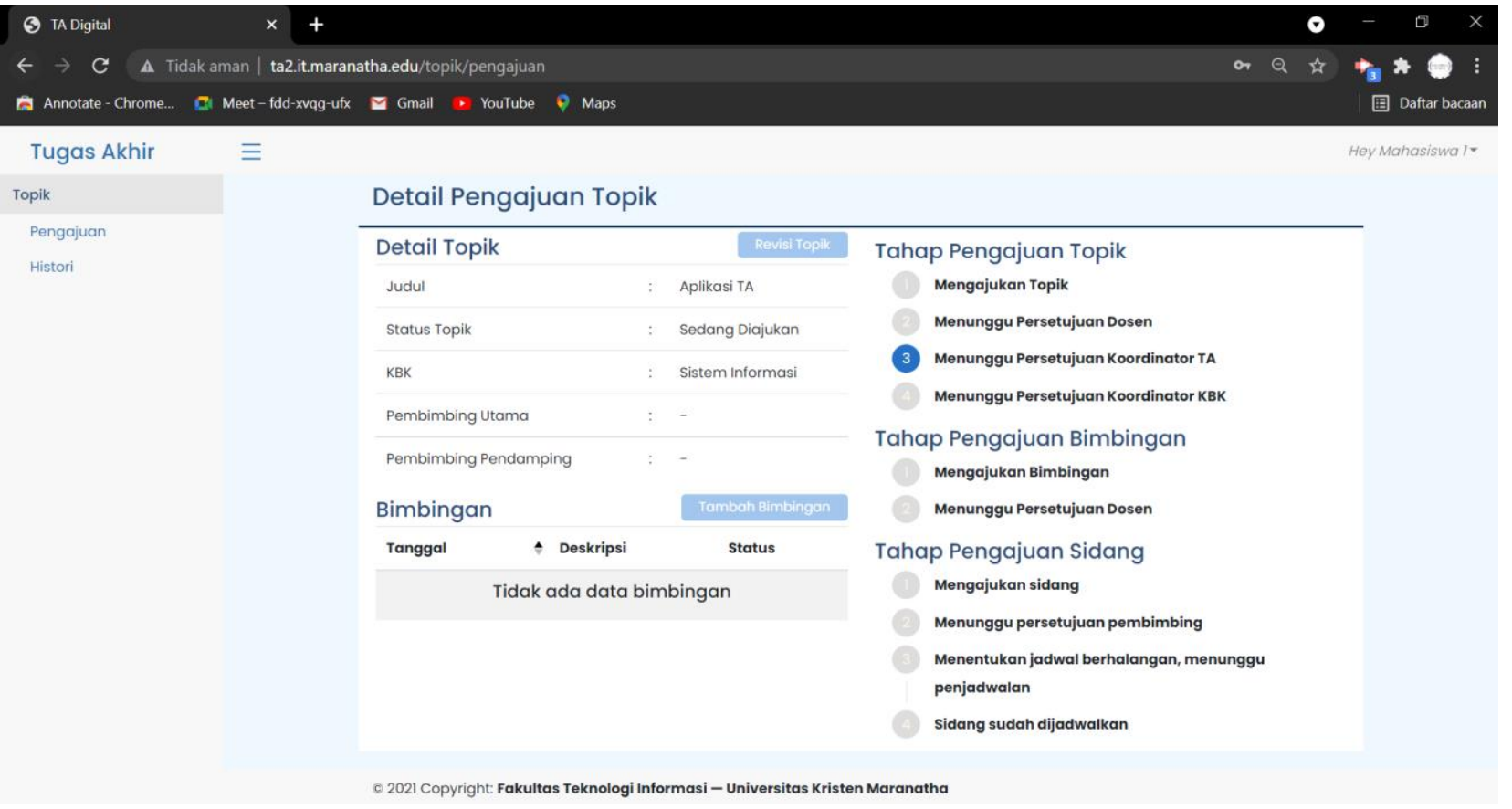

Gambar 11. Tampilan Pengajuan Topik dari Mahasiswa (2) 
Berikut ini merupakan tampilan detail topik yang diajukan mahasiswa pada akun Koordinator Tugas Akhir yang mengelola proses pengajuan topik. Dimana Koordinator dapat melihat keseluruhan informasi pengajuan topik dan status akhir kelengkapan dokumen. Tampilan aplikasi disajikan pada Gambar 12 ada laporan/report yang dihasilkan dapat menjadi file .xls dan dapat dilakukan penyaringan data (advance filter).

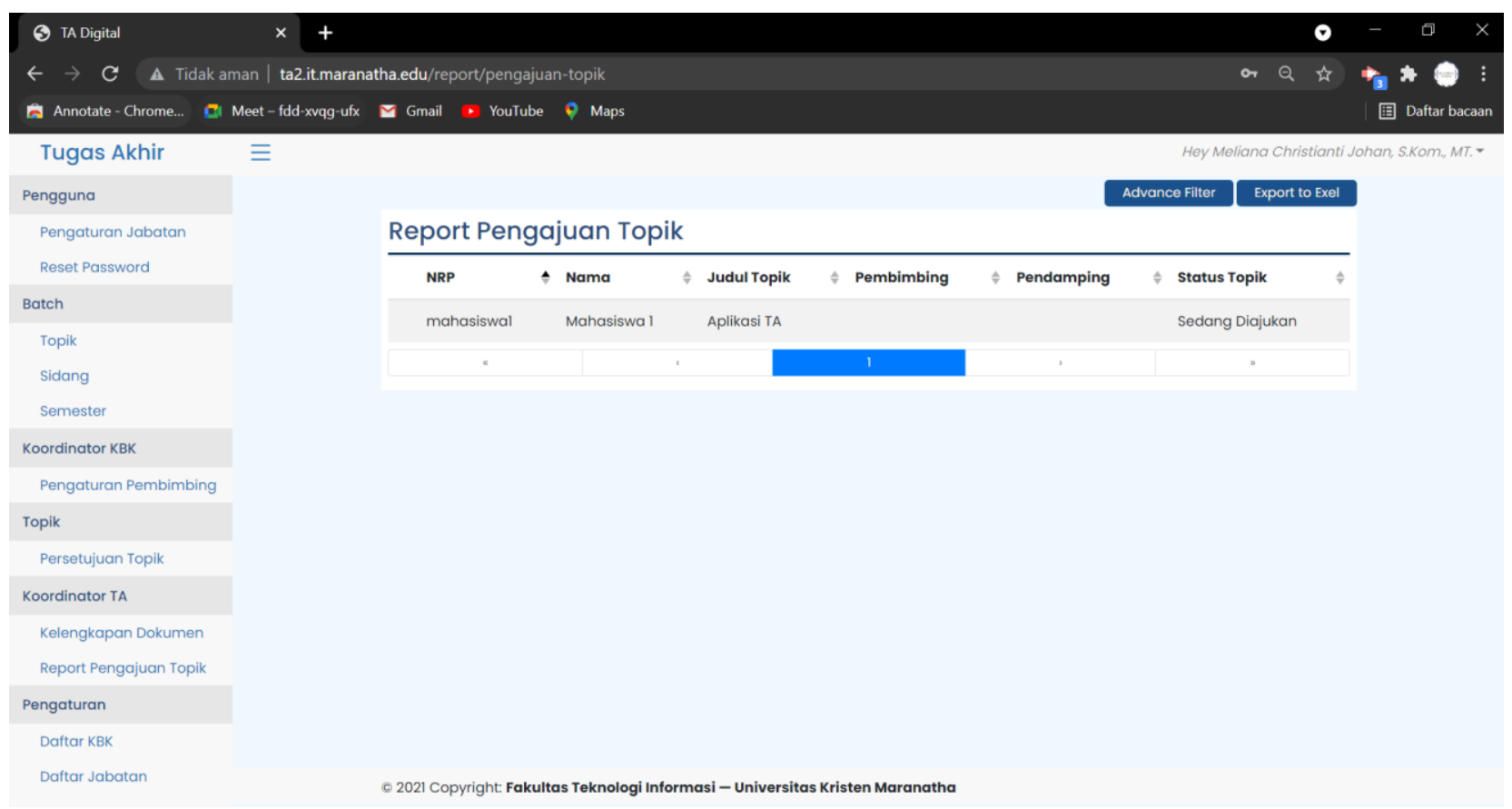

Gambar 12. Tampilan Report Pengajuan Topik untuk Koordinator TA

\section{IV.SIMPULAN}

Berdasarkan hasil analisis dan perancangan aplikasi terhadap aplikasi dapat ditarik kesimpulan bahwa aplikasi yang dihasilkan dapat berfungsi dengan baik dan dapat digunakan dalam proses pengajuan topik mahasiswa. Pada saat pengujian yang telah dilaksanakan melibatkan mahasiswa, koordinator TA, Koordinator KBK, Perwakilan dosen dan developer menggunakan black box testing dan menguji keseluruhan proses pengajuan topik dapat disimpulkan bahwa aplikasi dapat digunakan untuk mengelola data mahasiswa yang mengajukan topik tugas akhirnya di Program Studi S1 Teknik Informatika Universitas Kristen Maranatha Bandung. Aplikasi ini dibuat berbasis web sehingga membantu mahasiswa untuk mengajukan topik tugas akhir secara daring dan dapat dilakukan dimanapun sesuai jadwal pengajuan yang telah ditentukan oleh koordinator Tugas Akhir. Pengembangan aplikasi perlu dilanjutkan untuk proses bimbingan mahasiswa dengan dosen yang memungkinkan untuk dilakukan secara online dan terpusat. Demikianlah prototype aplikasi yang dihasilkan diimplementasikan pada Tahun Akademik 2021 / 2022 di Program Studi S1 Teknik Informatika Universitas Kristen Maranatha Bandung karena aplikasi ini diperlukan untuk dicoba menampung data pengajuan topik dari mahasiswa yang sudah perwalian dan mengambil mata kuliah Seminar Tugas Akhir.

\section{DAFTAR PUSTAKA}

[1] A. S. Mohammad and A. F. Ramadhan, "Aplikasi Bimbingan Kerja Praktek dan Tugas Akhir Mahasiswa Menggunakan Sistem Remote Database SQL," Jurusan Teknik Informatika Universitas Dayanu Ikhsanuddin Baubau, vol. 7, no. 1, 2017.

[2] M. Arifin, "Analisa Dan Perancangan Sistem Informasi Praktek Kerja Lapangan Pada Instansi/Perusahaan," Jurnal Simetris, vol. 5, no. 1, 2014.

[3] M. Septya, P. W. Putut and R. H. Heliza, "Rancang Bangun Sistem Informasi Praktek Kerja Lapangan (PKL) Di Fakultas Ilmu Komputer dan Teknologi Informasi Universitas Mulawarman," Jurnal Ilmiah ilmu komputer Informatika mulawarman, vol. 13, no. 2, 2018.

[4] insan and G. Alin, "Sistem Registrasi dan Monitoring Kerja Praktek Program Studi Teknik Informatika," Jurnal Sistem dan Teknologi Informasi (JustIN), vol. 2, no. 1, 2014.

[5] R. V. Imbar and A. , "Aplikasi Inventaris Judul KP dan TA dengan Bahasa Pemrograman PHP," Bandung, 2011.

[6] B. Alan and O. Karnalim, "Revitalizing Internship Registration Portal with an Implementation of Application Lifecycle Management," SISFORMA, 2018.

[7] S. Santoso, E. D. Handoyo and C. Chastro, Ultima Infosys, vol. XI, no. 2, pp. 90-96, 2020

[8] A. Nugroho, Rekayasa Perangkat Lunak Menggunakan UML \& Java, Yogyakarta: ANDI, 2010.

[9] J. Sihite and M. Johan., "Sistem Informasi Pengelolaan Daftar Kehadiran dan Jadwal Pembicara Berbasis Website Dengan Mail Gateway Pada 
Komunitas Jc Bandung”, JuTISI, vol. 3, no. 2, Aug. 2017.

[10] M. Johan., R. Tan, O. Karnalim, E. Imandha and T. Cahyadi, "Analisis dan Perancangan Aplikasi Penyusunan Jadwal Mengajar Sesuai Jadwal Kesediaan Mengajar Dosen Di Fakultas Teknologi Informasi (Studi Kasus : Jurusan Teknik Informatika)," Jurnal Teknik Informatika dan Sistem Informasi, vol. 1, no. 2, August 2015.

[11] M. Johan., R. Tan, B. Suteja, and N. Afiany, "Document Digitalization and Scoring System of Students Final Project", JuTISI, vol. 6, no. 3, Dec. 2020.

[12] M. Johan., R. V. Imbar, B. Suteja, and N. Syahputra, "Information System Analysis and Design for Final Assignment Exhibition", International Journal of Computer Science Issues, vol. 17, no. 6, pp. 82-86, Nov. 2020. 